\title{
Corporate governance and cash policies of multinational corporations
}

\author{
Citation for published version (APA):
}

Beuselinck, C., Deloof, M., \& Vanstraelen, A. (2012). Corporate governance and cash policies of multinational corporations. METEOR, Maastricht University School of Business and Economics. METEOR Research Memorandum No. 013 https://doi.org/10.26481/umamet.2012013

Document status and date:

Published: 01/01/2012

DOI:

10.26481/umamet.2012013

Document Version:

Publisher's PDF, also known as Version of record

\section{Please check the document version of this publication:}

- A submitted manuscript is the version of the article upon submission and before peer-review. There can be important differences between the submitted version and the official published version of record.

People interested in the research are advised to contact the author for the final version of the publication, or visit the DOI to the publisher's website.

- The final author version and the galley proof are versions of the publication after peer review.

- The final published version features the final layout of the paper including the volume, issue and page numbers.

Link to publication

\footnotetext{
General rights rights.

- You may freely distribute the URL identifying the publication in the public portal. please follow below link for the End User Agreement:

www.umlib.nl/taverne-license

Take down policy

If you believe that this document breaches copyright please contact us at:

repository@maastrichtuniversity.nl

providing details and we will investigate your claim.
}

Copyright and moral rights for the publications made accessible in the public portal are retained by the authors and/or other copyright owners and it is a condition of accessing publications that users recognise and abide by the legal requirements associated with these

- Users may download and print one copy of any publication from the public portal for the purpose of private study or research.

- You may not further distribute the material or use it for any profit-making activity or commercial gain

If the publication is distributed under the terms of Article $25 \mathrm{fa}$ of the Dutch Copyright Act, indicated by the "Taverne" license above, 


\section{Maastricht University}

Christof Beuselinck, Marc Deloof, Ann Vanstraelen

Corporate governance and cash policies of multinational corporations

RM/12/013

\section{METEOR}

Maastricht University School of Business and Economics

Maastricht Research School of Economics

of Technology and Organization

P. B. Box 616

NL -6200 MD Maastricht

The Netherlands 


\title{
Corporate Governance and Cash Policies of Multinational Corporations
}

\author{
Christof Beuselinck \\ Tilburg University \\ E-mail: C.Beuselinck@uvt.nl
}

Marc Deloof (*)

University of Antwerp and Louvain School of Management, Université catholique de Louvain

Ann Vanstraelen

Maastricht University

a.vanstraelen@maastrichtuniversity.nl

February 2012

(*) Corresponding author: Marc Deloof, Department of Accounting and Finance, University of Antwerp, Prinsstraat 13, 2000 Antwerp, Belgium; Email: marc.deloof@ua.ac.be; Phone: +32-3-265 4169; Fax: +32-3-265 4064 .

We would like to thank Marco Bigelli, Nico Dewaelheyns, Yan Du, Laurent Frésard, Nancy Huyghebaert, Aydin Ozkan and Marc Schauten for helpful comments and suggestions. The paper has also benefited from presentations at the Symposium on International Corporate Finance and Governance in Twente, the KUL/UCL Finance Research Workshop in Brussels, the Empirical Corporate Finance Workshop in Leuven and a seminar at the University of Hull. 


\title{
Corporate Governance and Cash Policies of Multinational Corporations
}

\begin{abstract}
This study investigates cash policies of multinational corporations (MNCs) for a large sample of European MNCs and their subsidiaries in the period 1998-2004. The results are consistent with the hypothesis that cash holdings depend on a trade-off between the superior knowledge of the subsidiary over headquarters and the agency costs of discretionary behavior by the subsidiary's management. We find that foreign subsidiaries hold more cash than domestic subsidiaries, although geographical distance from headquarters does not seem to matter. Horizontal subsidiaries hold more cash than vertical subsidiaries. Furthermore, we find that subsidiaries hold more cash if they are located in a country with better law enforcement and lower corruption. This result is consistent with the argument that better corporate governance in the subsidiary country reduces the risk of expropriation by the subsidiary management. Finally, the availability of external finance in the subsidiary country reduces the level of subsidiary cash holdings.
\end{abstract}

Keywords: cash holdings, multinational corporations, parent-subsidiary relationship, shareholder protection, law enforcement, Europe

JEL-classification codes: F23, G32, G38 


\section{Introduction}

Why do firms hold cash? An extensive academic literature has focused on asymmetric information between firms and outside investors, and agency problems between shareholders and self-interested managers to explain cash holdings (e.g., Opler et al., 1999; Ozkan and Ozkan, 2004). Firms use cash to finance their activities and investments when asymmetric information and agency costs make it difficult to raise external financing. In manager controlled firms, self-interested managers prefer to hold large cash reserves in the firm. These reserves allow them to escape capital market discipline and give them the flexibility to pursue their personal interests at the expense of the shareholders (Jensen, 1986). In particular, managers will find it easier to use cash for their personal interests when the quality of corporate governance is poor. It has therefore been argued that better corporate governance at the country level will make it easier for shareholders to control managers, and lead to lower cash holdings (Dittmar et al., 2003; Kalcheva and Lins, 2008). Furthermore, shareholders will value cash holdings higher if corporate governance is better, because better corporate governance reduces the risk that managers will use cash for their own interests (Pinkowitz et al., 2006; Dittmar and Mahrt-Smith, 2007; Frésard and Salva, 2010).

In the current study, we investigate cash holdings of multinational corporations (MNCs) and their subsidiaries, i.e. legally independent entities which are controlled by the MNC. Surprisingly, the existing literature pays little attention to cash policies in MNCs. A notable exception is Foley et al. (2007), who analyze the impact of repatriation taxes on US multinational cash holdings. ${ }^{1}$ MNC cash policies are particularly interesting to study for several reasons. First, existing studies of the impact of firm-level corporate governance on cash holdings typically focus on agency problems between management and shareholders of listed firms. However, the agency-relationship between MNC headquarters and subsidiaries is

\footnotetext{
${ }^{1}$ Other studies have focused on dividend policy (Desai et al., 2007) and debt policy (e.g., Desai et al., 2004b; Huizinga et al., 2008) within multinational firms, or on cash policy within business groups (Deloof, 2001).
} 
fundamentally different from the shareholder-management relationship in listed firms. Subsidiaries are typically majority (or even fully) owned by the MNC, which should give headquarters the power to punish subsidiary managers if any misbehavior is found out. On the other hand, the superior knowledge of a subsidiary over headquarters (for example about local markets), and the geographical distance between headquarters and the subsidiary make it more difficult for headquarters to control the subsidiary. It can therefore be expected that the extent to which headquarters allows subsidiaries to hold cash depends on a trade-off between the superior knowledge of the subsidiary over headquarters and the agency costs of discretionary behavior by the subsidiary's management. Second, MNCs operate across different countries with different corporate governance regimes, which will often deviate from corporate governance practices in the MNC home country. This raises the question how local corporate governance regimes affect the cash policy of subsidiaries. By investigating the impact of country-level corporate governance on cash holdings of foreign subsidiaries, this study provides a new perspective on the relationship between country-level corporate governance and firm cash holdings. Third, it is important to gain a better understanding of MNC financing policies, since in recent decades MNCs have become increasingly important in a globalizing world (e.g., UNCTAD 2005).

Our results are based on a large sample of listed MNCs in ten European countries and their majority-owned subsidiaries in 16 European countries over the period 1998-2004. We find that foreign subsidiaries hold more cash than domestic subsidiaries. This is consistent with the argument that the informational advantage of the subsidiary over headquarters is greater for foreign subsidiaries because they operate in an environment that is different from the MNC home country. On the other hand, geographical distance from headquarters does not seem to affect the cash holdings of foreign subsidiaries. We also find that horizontal subsidiaries, which operate in the same industry as the parent, hold more cash than other 
subsidiaries. This finding is consistent with the argument that horizontal subsidiaries operate more independently from headquarters than vertical subsidiaries, because of superior knowledge over and lower interdependence from headquarters (Alfaro and Charlton, 2009; Baliga and Jaeger, 1984). Further, we find some evidence that subsidiaries with minority shareholders hold more cash than fully owned subsidiaries; the latter being more likely to participate in an internal capital market of the MNC. Consistent with the argument that better corporate governance reduces the risk that the subsidiary management will expropriate cash from the controlling MNC, we find that MNC headquarters allows subsidiaries to hold more cash if they are located in a country with better law enforcement and lower corruption. Finally, we show that subsidiary cash holdings are negatively related to the availability of external financing in the subsidiary country, confirming the hypothesis that external financing reduces the need to hold cash.

The remainder of the study is organized as follows. Section 2 discusses the effect of the headquarters-subsidiary relationship and country-level corporate governance on subsidiary cash holdings. Section 3 specifies the research design. Section 4 reports the empirical findings of this study and section 5 concludes.

\section{Determinants of subsidiary cash holdings}

\subsection{The headquarters-subsidiary relationship}

The relationship between subsidiaries and headquarters in MNCs has a principal-agent structure. Since headquarters depend on the unique knowledge of its subsidiaries it has to delegate work and responsibilities to subsidiaries. However, self-interested subsidiary management may take decisions that are not congruent with those desired by headquarters (e.g., Nohria and Ghosal, 1994; O'Donnell, 2000; Roth and O'Donnell, 1996). This agency problem is potentially larger for foreign subsidiaries, because the absence of proximity can 
make it especially difficult for headquarters to supervise the behavior of foreign subsidiary managers (e.g., Baliga and Jaeger, 1984; O’Donnell, 2000).

According to Aghion and Tirole (1997), the key to delegating authority in a principalagent structure is asymmetric information. A principal will delegate authority to the agent if this agent is better informed and if her objectives do not deviate too much from those of the principal. However, when the interests of the principal and the agent are not perfectly aligned, the agent can use her informational advantage to make choices that are not in the best interest of the principal. As a result, the degree to which the principal delegates authority to the agent will be determined by the tradeoff between the agent's superior knowledge and the agency costs of delegation to the agent (e.g., Acemoglu et al., 2007). It can therefore be expected that within MNCs, the extent to which headquarters delegate authority to a subsidiary depends on the superior knowledge of the subsidiary over headquarters on the one hand, and the agency costs of discretionary behavior by the subsidiary's management on the other hand.

Subsidiaries operating more independently from headquarters are unlikely to be involved in an internal capital market of the MNC, since the benefits of shifting funds between business units via an internal capital market depend on the ability of headquarters to monitor and control these business units (Gertner et al., 1994; Stein, 1997). Independent subsidiaries are therefore likely to hold more cash for precautionary reasons and to minimize transaction costs. The precautionary motive for holding cash implies that a subsidiary can use cash to finance its activities and investments if other financial sources are not available or are excessively costly, while the transaction motive implies that holding cash saves transaction costs to raise money and avoids the need to liquidate assets in order to make payments (e.g., Opler et al., 1999). In our analysis we will consider four characteristics that reflect subsidiary independence based on the extent to which the subsidiary has superior knowledge over headquarters and the potential agency problems between headquarters and the subsidiary: (1) 
foreign versus domestic subsidiaries, (2) fully owned versus partially owned subsidiaries, (3) horizontal versus vertical subsidiaries, and (4) geographical distance between headquarters and subsidiaries.

First, we expect that foreign subsidiaries operate more independently from headquarters and hold more cash than domestic subsidiaries. As foreign subsidiaries operate in an environment that is different from the MNC home country, this is likely to result in greater superior knowledge of the subsidiary over headquarters compared to domestic subsidiaries. Hence, it can be expected that MNCs allow foreign subsidiaries to hold more cash. $^{2}$

Second, subsidiary cash holdings may be affected by the presence of minority shareholders in the subsidiary. The direction of this potential association, however, is a priori unclear. On the one hand, subsidiaries with minority shareholders may operate more independently from headquarters and hold more cash. The presence of minority shareholders makes it more difficult to tailor subsidiary activities to the needs of the MNC. Internal capital markets, internal product markets and tax-induced income shifting within the MNC create room for conflicts with the minority shareholders who have competing goals (e.g., Desai et al., 2004a). On the other hand, it could be argued that incomplete ownership of subsidiaries by the MNC decreases cash holdings because incomplete ownership impairs the ability of headquarters to monitor and control the management of the subsidiary. Partial ownership of foreign subsidiaries by local firms increases the risk that the subsidiary's management will pursue related-party transactions that are not in the interest of the parent. A rigid policy to pay out cash may help to control subsidiary management by limiting its financial discretion. Consistent with this conjecture, Desai et al. (2007) find that foreign affiliates of US MNCs pay dividends on a more regular basis if they are not fully owned by the MNC.

\footnotetext{
${ }^{2}$ Another reason why foreign subsidiaries may hold more cash than domestic subsidiaries is that corporate income paid out as a dividend to the parent may be taxed both in the subsidiary country and the parent country (e.g., Huizinga et al. 2008).
} 
Third, we consider whether the subsidiary operates in the same industry as the parent. Subsidiaries operating in the same industry as the parent are horizontal subsidiaries producing the same line of goods/services as the parent, while subsidiaries operating in an industry different from the MNC's main industry are vertical subsidiaries (Alfaro and Charlton, 2009). Baliga and Jaeger (1984) argue that the extent of delegation provided to the subsidiary management will be determined by the role a subsidiary plays in the overall functioning of the MNC. The management of a subsidiary targeting a market which requires specific knowledge that headquarters do not have, will be accorded a higher level of delegation than the management of a subsidiary which is critical to the overall functioning of the MNC (e.g., a provider of key inputs). Moreover, the extent to which a subsidiary is allowed to operate independently will depend on the degree of interdependence between the subsidiary and headquarters. Horizontal subsidiaries are more likely to target local markets or market segments that require specific knowledge, while vertical subsidiaries tend to be important for the overall functioning of the MNC making the latter more strongly integrated with the parent's activities. Hence, because horizontal subsidiaries generally operate more independently from headquarters than vertical subsidiaries, we expect horizontal subsidiaries to hold more cash than vertical subsidiaries.

Fourth, cash holdings of foreign subsidiaries may be affected by geographical distance between headquarters and the subsidiary. Some recent studies have found that despite the abundance of alternative modern communication technologies, geographical distance still matters in finance (e.g., Degryse and Ongena, 2005; Malloy, 2005; Uysal et al., 2008). In MNCs, headquarters face higher costs of gathering information about the subsidiary's activities if geographical distance is greater. The extent to which a subsidiary is integrated with the MNC and shares its overall strategy, goals and values will be based on the extent of face-to-face communication, informal interaction and travel of managers between 
headquarters and the subsidiary (e.g., Ghoshal and Bartlett, 1988; Gupta and Govindarajan, 1994, 2000). Geographical distance between headquarters and the subsidiary will make this kind of interaction more difficult or more costly (e.g., Carlin et al., 2007). Hence, subsidiaries at a larger distance from headquarters are likely to operate more independently, and can therefore be expected to hold more cash. Furthermore, since distance also makes it more difficult for headquarters to control the subsidiary, self-interested subsidiary managers may prefer to hold more cash because it gives them the flexibility to pursue their personal interests at the expense of shareholders (Jensen, 1986; Myers and Rajan, 1998; Pinkowitz et al., 2006).

\subsection{Country-level corporate governance}

Cash holdings of foreign subsidiaries are arguably affected by the quality of corporate governance in the subsidiary country. It can be expected that a better law enforcement and lower corruption in the subsidiary country have a positive effect on cash holdings of subsidiaries, since a better law enforcement and lower corruption reduce the agency costs associated with discretionary behavior by the subsidiary's managers. Managers of foreign subsidiaries located in a country with a better law enforcement and lower corruption may be allowed to operate more independently from headquarters and hold more cash. This can be expected as there is a lower likelihood that they will "steal" this cash from the controlling MNC, and the odds are higher that the controlling MNC will get "stolen" cash back if contracts are well enforced and respected in the subsidiary country. Hence, this results in a predicted positive (negative) relation between law enforcement (corruption) in the subsidiary's country and cash held by the subsidiary.

However, there are two arguments against finding a positive relation between countrylevel corporate governance and subsidiary cash holdings. The first argument is based on the idea that managers will find it easier to pursue their own interests when law enforcement is poor and corruption is high. As noted, large cash reserves allow self-interested managers to 
avoid capital market discipline and to pursue their personal interests at the expense of the shareholders. Consistent with this prediction, Dittmar et al. (2003) find that firms hold much more cash if they are located in a country where shareholder rights are not well protected. The results of Kalchava and Lins (2007) suggest that cash holdings are positively related to the degree of managerial control, and that this relation is stronger when external country-level shareholder protection is weak. ${ }^{3}$ It is unlikely, however, that this argument against finding a positive association between country-level corporate governance and subsidiary cash holdings applies to majority controlled subsidiaries of MNCs. Since the MNC has majority control, it can punish subsidiary managers if misbehavior is found out. Furthermore, Harford et al. (2008) argue that large unused cash balances may be a too visible indicator of agency problems. Consistent with this conjecture, they find a positive relation between the quality of corporate governance and cash holdings of US firms.

The second argument against finding a positive relation between country-level corporate governance and subsidiary cash holdings is based on the observation that capital markets are typically less developed in countries with poor investor protection (La Porta et al., 1997). Corporate governance at the country level may therefore have an indirect effect on cash holdings via their impact on the development of capital markets. If the availability of external finance in the subsidiary country is limited, subsidiaries may respond by holding higher cash balances to finance their investments (e.g., Islam and Mozumdar, 2007). This implies a negative relation between the availability of external financing in the subsidiary country and the subsidiary's cash holdings. When investigating the direct effect of countrylevel corporate governance on firm cash holdings, it is therefore important to control for the indirect effect of country-level corporate governance via its impact on the availability of external financing (Dittmar et al., 2003; Lins and Kalcheva, 2007).

\footnotetext{
${ }^{3}$ Investors also value cash holdings higher if the quality of corporate governance is better because there is less risk that managers will use cash for their own interests (Pinkowitz et al., 2006; Dittmar and Mahrt-Smith, 2007; Frésard and Salva, 2010).
} 


\section{Research design}

\subsection{Sample}

Data on subsidiaries and consolidated MNCs come from the June 2005 version of the Top 1,500,000 Amadeus database, supplied by Bureau van Dijk. This dataset provides comprehensive financial statement and ownership data for the 1.5 million largest (in terms of sales and total assets) public and private European companies and is compiled from several well-established national information collectors. We first consulted the Amadeus subsidiary ownership database to retrieve all listed, non-financial firms located in European countries with consolidated financial statements of which we can retrieve exact subsidiary ownership information on at least one subsidiary located within Europe: subsidiary identification code, subsidiary country of residence and exact ownership percentage held in the subsidiary. From these MNCs, we retrieved all European subsidiaries in which the MNC had a direct equity stake of at least 50\%; which have non-zero total assets; and for which all necessary information for the empirical analysis was available in the period 1998-2004. The final sample consists of 6,545 MNC-year observations for 1,271 unique MNCs and 13,321 subsidiary-year observations for 3,607 unique subsidiaries relating to 16 European countries, with 8,321 subsidiary-year observations for 2,332 domestic subsidiaries and 5,000 subsidiaryyear observations for 1,275 foreign subsidiaries, all in the period 1998-2004.

\subsection{Country-level corporate governance}

We use three measures of country-level corporate governance. Rule of law is the country-level 'rule of law' score for each year developed by the World Bank (Kaufmann et al. 2007). This score measures for 212 countries and territories the extent to which agents have confidence in and abide by the rules of society, and in particular the quality of contract enforcement, the police, and the courts, as well as the likelihood of crime and violence. 
Control of corruption is the country-level 'control of corruption' score for each year developed by the World Bank, and measures the exercise of public power for private gain, including both petty and grand corruption and state capture. ${ }^{4}$ Corruption Perception is the yearly Corruption Perceptions Index (CPI) of Transparency International (www.transparency.org). The CPI is an aggregate indicator that ranks countries in terms of the degree to which corruption is perceived to exist among public officials and politicians. The index ranges between 0 and 10. For all three measures, a higher score implies better corporate governance.

As noted in section 2.2, investor protection may indirectly reduce the need for firms to hold cash because it increases the availability of external financing in a country. To capture indirect effects of corporate governance on cash holdings, we measure the availability of external financing in the country by private credit, which is domestic credit to the private sector as a \% of GDP in each year (Dittmar et al., 2003; Kalcheva and Lins, 2007).

$$
* * * \text { Table } 1 \text { about here } * * *
$$

Table 1 reports the 2004 values for country corporate governance characteristics, as well as the number of MNC observations and subsidiary observations for each country in the sample. In our sample, the best corporate governance scores are for the Scandinavian countries, Austria and Switzerland, and the worst scores are for Eastern European countries, Greece and Italy. All countries in our sample have a rule of law and control of corruption score well above the worldwide average of zero, but the CPI-score of the Slovak Republic (4.0) is slightly below the 2004 worldwide average of $4.16 .^{5}$

\subsection{Other variables}

\footnotetext{
${ }^{4}$ Since rule of law and control of corruption scores are not available for 1999 and 2001, we used the score of the previous year for these years.

${ }^{5}$ The worldwide maximum is 2.018 for rule of law, 2.456 for control of corruption and 9.7 for corruption perception, and the worldwide minimum is -2.312 for rule of law, -1.775 for control of corruption and 1.5 for corruption perception.
} 
In line with existing literature on cash holdings (e.g., Opler et al., 1999), the dependent variable in all regressions is the natural log of cash and cash equivalents over net assets, which is calculated as total assets less cash and cash equivalents.

With respect to the relation between the MNC and its subsidiaries, we consider a domestic subsidiary dummy which is equal to one if the subsidiary is located in the same country as the parent and zero otherwise. Fully owned is a dummy equal to one if the subsidiary is fully owned by the parent and zero otherwise. Horizontal subsidiary is a dummy equal to one if the subsidiary has the same 2 digit NACE code as the parent, and zero otherwise (Alfaro and Charlton, 2009). For foreign subsidiaries, distance is the geographical distance between the capital cities of home country and subsidiary country (expressed in 1,000 kilometers).

Cash holdings by subsidiaries may be affected by the corporate income tax system. EU countries apply the recommended OECD practice (OECD 1997) which allows for a bilateral country choice between source-based taxation and residence-based taxation. In a source-based system, firms pay taxes on foreign income abroad only, causing their foreignsource income marginal tax rate being equal to the foreign tax rate. Foreign source income is exempted from taxes in the home country, and the MNC pays no additional tax in the home country. In a residence-based system, the home country taxes income generated abroad but provides tax credits for taxes already paid abroad. It may therefore be expected that foreign subsidiaries will on average hold less cash if a source-based system applies, because income paid by the subsidiary to the parent will be exempted from additional taxes in a source-based system. In a residence-based system by contrast, the parent company may still have to pay additional taxes on this income when repatriating these funds to the home country. In other words, in a residence-based system it may be preferable to leave excess cash in a foreign subsidiary instead of paying it out to the parent. We therefore include in our regressions a 
control variable tax credit, which is a dummy equal to one if the home country grants credits for taxes paid in the subsidiary country (i.e. operates under a residence-based taxation system), and zero otherwise. If the tax credit system provides an impediment for the subsidiary to pay out cash to its parent, the tax credit should have a positive coefficient.

Further, it can be argued that the cash policy of individual subsidiaries will be influenced by the overall cash policy of the MNC. Subsidiaries are likely to hold more cash if the MNC to which they belong holds more cash. We therefore include the natural log of MNC consolidated cash scaled by MNC consolidated net assets as a determinant of subsidiary cash holdings.

Additionally, we consider subsidiary-specific controls that are commonly used in the literature on corporate cash holdings (e.g., Opler et al., 1999; Ozkan and Ozkan, 2004; D'Mello et al., 2008). The natural log of net assets measures firm size. If economies of scale exist for cash holdings, one would expect firm size to be negatively related to cash holdings. Our cash flow measure is EBITDA over net assets. Firms with a high cash flow can save more cash. Leverage is short- and long-term debt over net assets. According to the pecking order model, firms with a surplus of internal funds will accumulate cash and pay back debt, while firms with a deficit of internal funds will decrease cash holdings and raise debt. Net working capital, which is measured by inventories plus receivables minus payables over net assets, could be a substitute for cash holdings. Intangibility is intangible fixed assets over total fixed assets and measures the extent to which the firm has firm-specific assets, which cannot be easily converted into cash. Moreover, in case of financial distress they cannot be liquidated at their intrinsic value and therefore provide an incentive to hold more cash. Capital expenditures are calculated as the change in book value of fixed assets plus depreciation over net assets. A firm that invests more is likely to have fewer internal resources. All regressions reported in this paper also include year dummies and industry dummies at the one digit 
NACE level. Our sample only includes non-financial MNCs. However, the main activity of a limited number of subsidiaries is financial intermediation (NACE 65 and 67). In the regressions for the subsidiaries, we therefore also include a financial subsidiary dummy that equals one if the subsidiary is in NACE industries 65 or 67.

In the empirical analysis, we will not only consider the determinants of subsidiary cash holdings but also the determinants of MNC consolidated cash holdings to see whether these are in line with results from prior research. All determinants of consolidated cash holdings are defined in the same way as in the analysis of subsidiary cash holdings. Additionally we include the natural log of the number of countries worldwide in which the MNC has subsidiaries, as a measure of complexity and the extent of internationalization of the MNC. Since all the MNCs in our sample are listed, we also include the market-to-book ratio. Market-to-book is the market value over the book value of equity and measures the extent to which the firm has firm-specific assets, which cannot be easily converted into cash. It is often also used as proxy for investment opportunities. Firms with valuable investment opportunities, for which the cost of external financing is high, are likely to hold more cash since the cost of being short of funds is high (Myers, 1977).

$$
\text { *** Table } 2 \text { about here *** }
$$

Table 2 reports statistics for MNCs (6,545 observations), domestic subsidiaries (8,321 observations) and foreign subsidiaries (5,000 observations). There is wide variation in cash holdings. The median MNC in our sample has consolidated cash holdings equal to approximately $6 \%$ of net assets (mean is $14 \%$ ). The median domestic and foreign subsidiaries have cash equal to $3.4 \%$ and $4.2 \%$ of net assets (means are $17.1 \%$ and $15.0 \%$ respectively). Further, the median MNC has subsidiaries in 5 different countries (mean is 8.611). $54.8 \%$ of the domestic subsidiaries and $42.6 \%$ of the foreign subsidiaries operate in the same 2 digit 
industry as their parent company. Approximately $83 \%$ of the subsidiaries are fully owned by the parent company.

*** Table 3 about here ***

Pearson correlation coefficients between subsidiary and subsidiary country characteristics are reported in Table 3 . The correlations for distance, tax credit and subsidiary country characteristics are calculated for foreign subsidiaries only. The table illustrates that it is important to consider the availability of private credit in a country, which is strongly and positively related to rule of law, control of corruption and perception of corruption in the country.

*** Table 4 about here $* * *$

\section{Results}

\subsection{MNC consolidated cash holdings}

Before considering subsidiary cash holdings, we first investigate the determinants of MNC consolidated cash holdings. This allows us to assess the extent to which the determinants of cash holdings of the MNCs in our sample are comparable to those found in other studies. We estimate OLS regressions with robust standard errors clustered by MNCs. ${ }^{6}$ The regression models include determinants found in prior research and we add measures of corporate governance and the availability of private credit in the MNC home country. ${ }^{7}$ Results are reported in Table 4. The home country corporate governance measures are not significantly related to MNC consolidated cash holdings, indicating that corporate governance in the home country does not matter much for the consolidated cash holdings of MNCs. A possible explanation for this result is that cash holdings of the foreign subsidiaries are affected

\footnotetext{
${ }^{6}$ Since the regressions include time-invariant variables we cannot include firm-fixed effects.

${ }^{7}$ Capital expenditures are not included in the MNC-regressions because there are too many outliers for this variable in the MNC-sample.
} 
by corporate governance in the different subsidiary countries, rather than corporate governance in the MNC home country. Home country private credit on the other hand is significantly and negatively related to consolidated cash holdings, which indicates that the availability of external financing in the home country reduces the overall need for MNCs to hold cash. External financing obtained in the home country may be redistributed among foreign subsidiaries via an internal capital market. ${ }^{8}$

Ln(countries), which measures the complexity and the extent of internationalization of the MNC, is significantly and positively related to MNC consolidated cash holdings. This suggests that a higher degree of internationalization increases asymmetric information problems and creates transaction and tax costs of cross-border payments within the MNC. The results for the other variables are generally in line with previous findings in the literature: larger firms, firms with a higher leverage, a higher market-to-book ratio and more intangible assets hold significantly more cash. However, cash flow and net working capital are not significantly related to MNC consolidated cash holdings.

$$
\text { *** Table } 5 \text { about here } * * *
$$

\subsection{Subsidiary cash holdings}

Next, we investigate the relation between subsidiary cash holdings and headquarterssubsidiary characteristics. The results are reported in Table 5. In all regressions for subsidiary cash holdings, standard errors are clustered by MNCs and subsidiaries. ${ }^{9}$ Regression model 4 is estimated for the full sample, which includes both domestic and foreign subsidiaries. As expected, foreign subsidiaries hold more cash than domestic subsidiaries, and horizontal

\footnotetext{
${ }^{8}$ In unreported regressions (results available from the authors upon request) we find that better firm-level corporate governance also reduces cash holdings: MNCs with more institutional shareholders and analyst following hold significantly less cash.

${ }^{9}$ We used the Stata-routine written by Mitchell Petersen to cluster standard errors by two dimensions: see http://www.kellogg.northwestern.edu/faculty/petersen/htm/papers/se/se_programming.htm. Clustering standard errors by MNCs or subsidiaries alone does not alter any of the results reported in this paper (results available from the authors upon request).
} 
subsidiaries hold more cash than other subsidiaries. The coefficients of domestic subsidiary and horizontal subsidiary are statistically significant at the $1 \%$ level. The effects of domestic versus foreign subsidiaries and horizontal versus vertical subsidiaries are also economically significant. Since the dependent variable is the $\log$ of cash holdings, the coefficient of -0.471 for domestic subsidiary can be interpreted as an expected difference in cash holdings between domestic and foreign subsidiaries of $47.1 \%$. Likewise, horizontal subsidiaries are expected to hold $30.7 \%$ more cash than vertical subsidiaries. The fully owned coefficient on the other hand has the predicted negative sign but it is not statistically significant. The hypothesis that subsidiary cash holdings are affected by the presence of minority shareholders is therefore not confirmed.

As for the other variables included in the model, subsidiary cash holdings are strongly and positively related to MNC consolidated cash holdings. Subsidiaries hold more cash if the MNC overall holds more cash. In line with findings from prior research, subsidiaries hold more cash if they are smaller, have more intangible assets, generate higher cash flows, and invest less. ${ }^{10}$ One surprising finding is the significant positive relation between cash holdings and leverage. A possible explanation for this result could be that subsidiaries hold more cash after they received intragroup loans via the internal capital market of the MNC.

In a next step, we estimate separate regressions for domestic subsidiaries and foreign subsidiaries. The results for domestic subsidiaries (model 5) confirm the results for the full sample. Horizontal subsidiaries hold more cash, while the presence of minority shareholders is not related to subsidiary cash holdings. We find the same result for foreign subsidiaries in model 6, which includes two additional variables: distance and tax credit. The distance coefficient is insignificant and even has a negative sign, which suggests that geographical

\footnotetext{
${ }^{10}$ Again, when interpreting the results for these variables it should be taken into account that the dependent variable is the $\log$ of cash holdings. For example, the cash flow coefficient of 2.147 implies that a one standard deviation increase in cash flow increases cash holdings by $30.3 \%$.
} 
distance does not affect subsidiary cash holdings. ${ }^{11}$ The tax credit coefficient on the other hand is positive and significant at the $1 \%$ level, confirming that subsidiaries for which a residence based tax credit system applies hold more cash than subsidiaries for which income paid to the parent is tax exempted. As for the other control variables, it is interesting to note that leverage is not significantly related to foreign subsidiary cash holdings, which suggests that the cash policy of foreign subsidiaries is independent of their debt policy. Our finding that cash holdings of foreign subsidiaries are not related to leverage, while cash holdings of domestic subsidiaries are positively related to leverage is consistent with the conjecture that foreign subsidiaries are less likely to receive cash via intragroup loans than domestic subsidiaries because foreign subsidiaries tend to operate more independently from headquarters.

\section{*** Table 6 about here ***}

Table 6 reports results on the impact of subsidiary country-level corporate governance on subsidiary cash holdings. All regression models include the same control variables as before, but for brevity we only report results for the main variables of interest. The results for the control variables (available from the authors upon request) are fully consistent with the results in Table 5. Regression models 7, 8 and 9 consider the effect of rule of law, control of corruption and corruption perception respectively. All three measures of country corporate governance are significantly and positively related to subsidiary cash holdings, confirming the hypothesis that better law enforcement and lower (perceived) corruption in the subsidiary country provide an environment in which managers can be trusted to hold cash. For example, the difference of approximately 1.5 between the 2004 rule of law score of the weakest country (Slovak Republic: 0.478) and the strongest country (Switzerland: 1.973) in our sample implies an expected difference in cash holdings between subsidiaries in both countries of $90.3 \%$.

\footnotetext{
${ }^{11}$ The effect of distance remains insignificant if we consider the log of distance instead of distance.
} 
Furthermore, the availability of private credit in the subsidiary country is significantly and negatively related to subsidiary cash holdings, which is consistent with the argument that the availability of credit in the subsidiary country reduces the need for subsidiaries to hold cash. The private credit coefficient of -0.005 implies an expected difference in cash holdings of approximately $63.5 \%$ between subsidiaries in the country with the lowest availability of private credit in 2004 (Slovak Republic) and subsidiaries in the country with the highest availability of private credit (Switzerland). The opposing effects of the country corporate governance variables and the availability of private credit on subsidiary cash holdings confirm our expectations. Nevertheless they are remarkable given that Table 3 revealed that these variables are (unsurprisingly) strongly positively correlated.

$$
* * * \text { Table } 7 \text { about here } * * *
$$

\subsection{Robustness checks}

A majority of the MNC headquarters and the subsidiaries in our sample are located in France or the $\mathrm{UK}^{12}$ This raises the concern that our results are driven by specific characteristics of MNCs and subsidiaries in these countries. To investigate this issue, we reestimated the regressions in Tables 5 and 6 for a restricted sample which excludes MNCs and subsidiaries located in France or the UK. This restriction reduces the sample to 2,182 observations for domestic subsidiaries and 1,745 observations for foreign subsidiaries. The regression results, which are reported in Table 7 , generally confirm those for the original sample. Domestic subsidiaries hold less cash than foreign subsidiaries; horizontal subsidiaries hold more cash than other subsidiaries; a better rule of law and lower corruption increase cash holdings, while a higher credit available in the subsidiary country reduces its cash holdings. Additionally, the fully owned dummy is now significantly positive at the $10 \%$ level for

\footnotetext{
${ }^{12}$ This is to some extent a consequence of differences in the available data for different countries in the Amadeus database we used. For example the coverage of Belgium, France,and the UK is much wider than the coverage of Germany or the Netherlands.
} 
foreign subsidiaries, which is consistent with the hypothesis that the presence of minority shareholders makes it more difficult to tailor subsidiary activities to the needs of the MNC.

Another potential problem may arise from including MNC consolidated cash holdings as a determinant of subsidiary cash holdings since the cash held by the subsidiary will be incorporated in the consolidated cash holdings. For subsidiaries which are relatively large to the MNC, the cash they hold could therefore significantly affect consolidated cash holdings. To investigate whether this affects our results, we subtracted subsidiary cash holdings from consolidated cash holdings before including the log of consolidated cash holdings in the models. ${ }^{13}$ The results (available upon request) are very similar to those reported in the paper. We also re-estimated all subsidiary level regression models without MNC consolidated cash holdings. Again, results (available upon request) are qualitatively the same as the ones reported in the paper.

Additionally, we recoded the horizontal subsidiary dummy based on 4 digit NACE code instead of 2 digit NACE code. The results (available upon request) are again qualitatively the same as the ones reported in the tables.

\section{Conclusions}

This study provides evidence on the cash policies of multinational corporations. While there is an extensive literature on the determinants of cash holdings of firms, the role of cash in MNCs has so far been neglected. This is remarkable since MNCs play a crucial role in the global economy, and the agency-relationship between headquarters and subsidiaries in MNCs is fundamentally different from the shareholder-management relationship in most other firms. Furthermore, the fact that MNCs operate in foreign countries where corporate governance may be very different from the home country, raises the question how local corporate

\footnotetext{
${ }^{13}$ It should be noted that this approach in some cases leads to negative cash figures because the extent to which subsidiary cash holdings are incorporated in consolidated MNC cash holdings depends on consolidation rules, which we do not know.
} 
governance regimes affect the cash policy of subsidiaries. Our results are generally consistent with the hypothesis that cash holdings by MNC subsidiaries reflect the subsidiary's independence from headquarters. The independence of subsidiaries is determined by a tradeoff between the superior knowledge the subsidiary has over headquarters, and the agency costs of discretionary behavior by the subsidiary's management.

We find that foreign subsidiaries and horizontal subsidiaries, which typically have more specific knowledge over headquarters than domestic subsidiaries and vertical subsidiaries, hold more cash. We also find some evidence that subsidiaries with minority shareholders, which are less likely to participate in an internal capital market of the MNC also hold more cash. While geographical distance between the subsidiary and headquarters does not seem to matter, country-level corporate governance plays an important role. MNCs allow their foreign subsidiaries to hold more cash if there is a better law enforcement and lower corruption in the subsidiary country. Further, we find that subsidiaries hold less cash if there is more external financing available in the subsidiary country. The availability of external financing in the MNC home country reduces the overall cash holdings of the MNC. Finally, it is interesting to note that taxation also seems to have a significant effect on subsidiary cash holdings. Subsidiaries hold more cash if payouts to the MNC are likely to be taxed in the home country of the MNC. 


\section{References}

Acemoglu, D., Aghion, P., Lelarge, C., Van Reenen, J., Zilibotti, F., 2007. Technology, information, and the decentralization of the firm. Quarterly Journal of Economics 122, 17591799.

Aghion, P., Tirole, J., 1997. Formal and real authority in organizations. Journal of Political Economy 105, 1-29.

Alfaro, L., Charlton A., 2009. Intra-industry foreign direct investment. American Economic Review 99, 2096-2119.

Baliga, B.R., Jaeger, A.M., 1984. Multinational corporations: control systems and delegation issues. Journal of International Business Studies 15, 25-40.

Carlin, W., Charlton, A., Mayer, C., 2007. Multinational ownership and subsidiary investment. Working Paper, London School of Economics.

D’Mello, R., Krishnaswami, S., Larkin, P.J., 2008. Determinants of corporate cash holdings: Evidence from spin-offs. Journal of Banking and Finance 32, 1209-1220.

Degryse, H., Ongena, H., 2005. Distance, lending relationships, and competition. Journal of Finance 60, 231-266.

Deloof, M., 2001. Belgian intragroup relations and the determinants of corporate liquid reserves. European Financial Management 7, 375-392.

Desai, M.A., Foley, C.F., Hines Jr., J.R., 2004a. The costs of shared ownership: Evidence from international joint ventures. Journal of Financial Economics 73, 323-374.

Desai, M.A., Foley, C.F., Hines Jr., J.R., 2004b. A multinational perspective on capital structure choice and internal capital markets. Journal of Finance 59, 2451-2488.

Desai, M. A., Foley, C. F., Hines Jr., J. R., 2007. Dividend policy inside the firm. Financial Management 36, 5-26.

Dittmar, A., Mahrt-Smith, J., Servaes, H., 2003. International corporate governance and corporate cash holdings. Journal of Financial and Quantitative Analysis 38, 111-133.

Dittmar, A., Mahrt-Smith, J., 2007. Corporate governance and the value of cash holdings. Journal of Financial Economics 83, 599-634.

Foley, C.F., Hartzell, J.C., Titman, S., Twite, G., 2007. Why do firms hold so much cash? A tax based explanation. Journal of Financial Economics 86, 579-607.

Frésard, L.,Salva, C., 2010. The value of excess cash and corporate governance: Evidence from U.S. cross-listings. Journal of Financial Economics, forthcoming.

Gertner, R.H., Scharfstein,, D.S., Stein., J.C, 1994. Internal versus External Capital Markets. Quarterly Journal of Economics 109, 1211-1230.

Ghoshal, S., Bartlett, C.A., 1988. Creation, adoption and diffusion of innovations by subsidiaries of multinational corporations. Journal of International Business Studies 19, 365388.

Gupta, A.K., Govindarajan, V., 1994. Organizing for Knowledge Flows within MNCs. International Business Review 43, 443-457. 
Gupta, A. K., Govindarajan, V., 2000. Knowledge Flows within the Multinational Corporation. Strategic Management Journal 21, 473-496.

Harford, J., Mansi, S.A., Maxwell, W.F., 2008. Corporate governance and firm cash holdings in the US. Journal of Financial Economics 87, 535-555.

Huizinga, H., Laeven, L., Nicodeme, G., 2008. Capital structure and international debt shifting. Journal of Financial Economics 88, 80-118.

Islam, S.S., Mozumdar, A., 2007. Financial market development and the importance of internal cash: Evidence from international data. Journal of Banking and Finance 31, 641-658.

Jensen, M., 1986. Agency costs of the free cash flow, corporate finance and takeovers American Economic Review 76, 323-329.

Kalcheva, I., Lins, K.V., 2007. International evidence on cash holdings and expected managerial agency problems. Review of Financial Studies 20, 1087-1112.

Kaufmann, D., Kraay, A., Mastruzzi., M., 2007. Governance Matters VI: Aggregate and Individual Governance Indicators 1996-2006. The World Bank.

La Porta, R., Lopez-de-Silanes, F., Shleifer, A., Vishny, R., 1997. Legal determinants of external finance. Journal of Finance 52, 1131-1150.

Malloy, C., 2005. The geography of equity analysis. Journal of Finance 60, 719-755.

Myers, S.C., 1977. Determinants of corporate borrowing. Journal of Financial Economics, 5, $147-175$.

Myers, S.C., Rajan, R.G., 1998. The paradox of liquidity. Quarterly Journal of Economics $113,733-771$.

Nohria, N., Ghoshal, S., 1994. Differentiated Fit and Shared Values, Alternatives for Managing Headquarters-Subsidiary Relations. Strategic Management Journal 15, 491-502.

O’Donnell, S., 2000. Managing Foreign Subsidiaries, Agents of Headquarters, or an Independent Network? Strategic Management Journal 21, 525-548.

Organization for Economic Cooperation and Development (OECD), 1997). Model tax convention on income and on capital, Paris.

Opler, T., Pinkowitz, L., Stulz, R., Williamson, R., 1999. The determinants and implications of cash holdings. Journal of Financial Economics 52, 3-46.

Ozkan, A., Ozkan, N., 2004. Corporate cash holdings: an empirical investigation of UK companies. Journal of Banking and Finance 28, 2103-2134

Pinkowitz, L., Stulz, R., Williamson, R., 2006. Does the contribution of corporate cash holdings and dividends to firm value depend on governance? A cross-country analysis. Journal of Finance 61, 2725-2751.

Roth, K., O’Donnell, S., 1996. Foreign subsidiary compensation strategy, an agency theory perspective. Academy of Management Journal 39, 678-703.

Stein, J.C., 1997. Internal capital markets and the competition for corporate resources. Journal of Finance 52, 111-133.

Uysal, V.B., Kedia, S., Panchapagesan, 2008. Geography and acquirer returns. Journal of Financial Intermediation 17, 256-275. 
United Nations Conference on Trade and Development (UNCTAD), World Investment Report, 2005. 


\section{Tables}

Table 1

Country characteristics in 2004

\begin{tabular}{lcrrrrr}
\hline & $\begin{array}{c}\text { Rule of } \\
\text { law }\end{array}$ & $\begin{array}{c}\text { Control of } \\
\text { corruption }\end{array}$ & $\begin{array}{c}\text { Corruption } \\
\text { perception }\end{array}$ & $\begin{array}{c}\text { Private } \\
\text { credit }\end{array}$ & $\begin{array}{c}\text { No. of } \\
\text { MNC obs. }\end{array}$ & $\begin{array}{c}\text { No. of } \\
\text { subsidiary obs. }\end{array}$ \\
\hline Austria & 1.802 & 2.095 & 8.4 & 105 & 0 & 13 \\
Belgium & 1.492 & 1.510 & 7.5 & 72 & 248 & 1,983 \\
Czech Republic & 0.699 & 0.362 & 4.2 & 33 & 0 & 25 \\
Finland & 1.897 & 2.456 & 9.7 & 68 & 375 & 953 \\
France & 1.393 & 1.442 & 7.1 & 90 & 1,091 & 4,086 \\
Germany & 1.708 & 1.911 & 8.2 & 112 & 604 & 174 \\
Greece & 0.822 & 0.570 & 4.3 & 70 & 0 & 227 \\
Hungary & 0.821 & 0.678 & 4.8 & 46 & 0 & 23 \\
Ireland & 1.569 & 1.511 & 7.5 & 135 & 6 & 15 \\
Italy & 0.666 & 0.608 & 4.8 & 85 & 248 & 781 \\
Netherlands & 1.751 & 2.021 & 8.7 & 158 & 395 & 220 \\
Slovak Republic & 0.478 & 0.996 & 4.0 & 30 & 0 & 24 \\
Spain & 1.202 & 1.414 & 7.1 & 125 & 106 & 171 \\
Sweden & 1.863 & 2.166 & 9.2 & 103 & 291 & 500 \\
Switzerland & 1.973 & 2.101 & 9.1 & 157 & 82 & 48 \\
United Kingdom & 1.713 & 1.989 & 8.6 & 153 & 3,099 & 4,078 \\
\hline Total: & & & & & 6,545 & 13,321 \\
\hline
\end{tabular}

Rule of law measures the extent to which agents have confidence in and abide by the rules of society, and in particular the quality of contract enforcement, the police, and the courts, as well as the likelihood of crime and violence (source: Kaufman, 2007); Control of corruption measures the exercise of public power for private gain, including both petty and grand corruption and state capture (source: Kaufman, 2007); Corruption perception measures the perceived public sector corruption (source: Transparency International); Private credit is domestic credit to private sector as a \% of GDP (source: World Bank). 
Table 2

Descriptive Statistics

\begin{tabular}{|c|c|c|c|c|c|c|c|c|c|}
\hline & \multicolumn{3}{|c|}{$\begin{array}{c}\text { MNCs } \\
\text { (6,545 MNC-year observations) }\end{array}$} & \multicolumn{3}{|c|}{$\begin{array}{c}\text { Domestic subsidiaries } \\
\text { (8,321 subsidiary-year observations) }\end{array}$} & \multicolumn{3}{|c|}{$\begin{array}{c}\text { Foreign subsidiaries } \\
(5,000 \text { subsidiary-year observations })\end{array}$} \\
\hline & Me an & Median & St. dev. & Mean & Median & St. dev. & Mean & Median & St. dev. \\
\hline Cash holdings & 0.140 & 0.067 & 0.218 & 0.171 & 0.034 & 0.457 & 0.150 & 0.042 & 0.380 \\
\hline Net assets & 4.43 bio $€$ & 121 bio $€$ & 22.6 bio $€$ & 199 mio $€$ & 17 mio $€$ & 783 mio $€$ & 234 mio $€$ & 24 mio $€$ & 804 mio $€$ \\
\hline Cash flow & 0.125 & 0.128 & 0.141 & 0.138 & 0.124 & 0.211 & 0.119 & 0.101 & 0.201 \\
\hline Leverage & 0.234 & 0.212 & 0.178 & 0.286 & 0.144 & 0.387 & 0.165 & 0.031 & 0.294 \\
\hline Net working capital & 0.246 & 0.234 & 0.191 & 0.206 & 0.167 & 0.266 & 0.281 & 0.271 & 0.273 \\
\hline Intangibility & 0.294 & 0.189 & 0.294 & 0.116 & 0.002 & 0.237 & 0.127 & 0.011 & 0.226 \\
\hline Market-to-book & 1.540 & 1.207 & 1.164 & & & & & & \\
\hline Countries & 8.611 & 5 & 12.105 & & & & & & \\
\hline Capital expenditures & & & & 0.065 & 0.034 & 0.137 & 0.053 & 0.029 & 0.136 \\
\hline Financial subsidiary & & & & $0.4 \%$ & & & $1.1 \%$ & & \\
\hline Horizontal subsidiary & & & & $54.8 \%$ & & & $42.6 \%$ & & \\
\hline Fully owned & & & & $82.5 \%$ & & & $83.7 \%$ & & \\
\hline Distance $(1,000 \mathrm{~km})$ & & & & & & & 0.763 & 0.652 & 0.519 \\
\hline Tax credit & & & & & & & $38.4 \%$ & & \\
\hline
\end{tabular}

Cash holdings is cash and cash equivalents over net assets; Net assets is total assets minus cash and cash equivalents; Cash flow is EBITDA over net assets; Leverage is short-term and long-term debt over net assets; Net working capital is (inventories plus receivables minus payables) over net assets; Intangibility is intangible fixed assets over total fixed assets; Market-to-book is the market value over the book value of assets; Countries is the number of countries (worldwide) in which the MNC has subsidiaries; Capital expenditures is the change in fixed assets over the year plus depreciation over net assets; Financial subsidiary is a dummy variable equal to one if the subsidiary is in NACE industries 65 or 67; Horizontal subsidiary is a dummy variable equal to one if the subsidiary is in the same 2 digit NACE industry as its parent; Fully owned is a dummy variable equal to one if the subsidiary is fully owned by its parent; Domestic subsidiary is a dummy variable equal to one if the subsidiary is located in the same country as its parent; Distance is the km distance between the capital cities of the home country and the subsidiary country; Tax credit is a dummy equal to one if the home country grants credits for taxes paid in the subsidiary country. 
Table 3

Pearson correlation coefficients

(1)

(2)

(3)

(4)

(5)

(6)

(7)

(8)

(9)

(10)

(11)

(13)

(14)

(15)

(16)

(17)

All subsidiaries (13,321 subsidiary-year observations)

(1) Ln(cash holdings)

(2) Ln(MNC cash holdings)

(3) Ln(net assets)

(4) Net working capital

(5) Cash flow

(6) Leverage

(7) Capital expenditures

(8) Intangibility

(9) Financial subsidiary

(10) Horizontal subsidiary

(11) Fully owned

(12) Domestic subsidiary
1.000

$0.251 \quad 1.000$

$\begin{array}{rrr}-0.277 & -0.170 & 1.000\end{array}$

$\begin{array}{llll}0.022 & \mathbf{0 . 0 5 0} & \mathbf{- 0 . 1 1 3} & \mathbf{1 . 0 0 0}\end{array}$

$\begin{array}{llll}0.176 & 0.035 & -0.071 & 0.095\end{array}$

$\begin{array}{llll}-0.002 & -0.091 & 0.035 & -0.105\end{array}$

$\begin{array}{llll}\mathbf{- 0 . 0 4 9} & \mathbf{- 0 . 0 2 4} & \mathbf{0 . 0 4 2} & \mathbf{- 0 . 1 2 3}\end{array}$

$\begin{array}{llll}0.047 & 0.050 & \mathbf{- 0 . 0 3 2} & \mathbf{- 0 . 0 2 8}\end{array}$

$\begin{array}{lll}-0.027 & -0.018 & \mathbf{0 . 0 3 0}\end{array}$

$\begin{array}{lll}0.051 & 0.035 & 0.104\end{array}$

$\begin{array}{lll}\mathbf{- 0 . 0 4 9} & \mathbf{- 0 . 1 0 9} & \mathbf{0 . 0 7 5}\end{array}$

$\begin{array}{lll}-0.032 & -0.042 & -0.073\end{array}$

\section{$\mathbf{- 0 . 0 2 8}-\mathbf{- 0 . 0 4 1}$}

$\mathbf{- 0 . 0 2 4} 0.004$

$\mathbf{- 0 . 0 7 9} 0.067$

$\mathbf{0 . 0 2 8} 0.011$

$-0.1350 .044$

\subsection{0}

$\mathbf{0 . 0 2 5} 1.000$

$\begin{array}{rrr}-0.031 & 0.046 & 1.000\end{array}$

$\begin{array}{lll}0.010 & 0.036 & -0.024\end{array}$

$\begin{array}{lll}\mathbf{0 . 0 2 4} & \mathbf{0 . 0 4 6} & -0.002\end{array}$

$\mathbf{0 . 1 2 9}-0.011 \quad \mathbf{- 0 . 0 5 3}$

$\mathbf{0 . 1 6 6} \mathbf{0 . 0 4 3}-0.022$

\subsection{0}

$\begin{array}{lll}\mathbf{0 . 0 3 2} & 0.021 & \mathbf{1 . 0 0 0}\end{array}$

$\begin{array}{lll}\mathbf{- 0 . 0 3 7} & \mathbf{0 . 1 1 9} & -0.015\end{array}$

Foreign subsidiaries (5,000 subsidiary-year observations)

\begin{tabular}{|c|c|c|c|c|c|c|c|c|c|c|c|c|c|c|c|c|}
\hline (13) Distance & -0.070 & -0.040 & 0.190 & 0.057 & 0.030 & -0.040 & 0.011 & 0.024 & -0.017 & 0.032 & 0.007 & 1.000 & & & & \\
\hline (14) Tax credit & 0.078 & -0.043 & 0.023 & -0.077 & -0.045 & -0.013 & 0.000 & 0.030 & -0.038 & 0.054 & 0.030 & 0.140 & 1.000 & & & \\
\hline (15) Rule of law & 0.056 & -0.036 & -0.055 & -0.010 & -0.058 & 0.139 & -0.039 & -0.118 & 0.049 & -0.045 & 0.066 & -0.337 & 0.068 & 1.000 & & \\
\hline (16) Control of corruption & 0.042 & -0.047 & -0.021 & 0.003 & -0.053 & 0.138 & -0.021 & -0.108 & 0.051 & -0.037 & 0.080 & -0.277 & 0.075 & 0.973 & 1.000 & \\
\hline (17) Corruption perception & 0.025 & -0.022 & 0.018 & 0.028 & -0.053 & 0.113 & -0.045 & -0.080 & 0.044 & -0.031 & 0.073 & -0.196 & 0.103 & 0.938 & 0.943 & 1.000 \\
\hline (18) Private credit & -0.055 & -0.009 & 0.054 & 0.057 & -0.072 & 0.132 & -0.036 & -0.049 & 0.007 & -0.057 & 0.032 & -0.096 & -0.009 & 0.476 & 0.503 & 0.487 \\
\hline
\end{tabular}

Bold indicates significance at the $1 \%$ level.

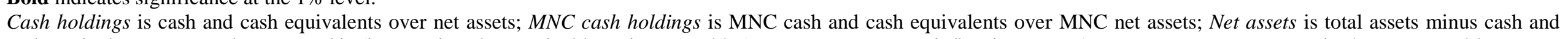

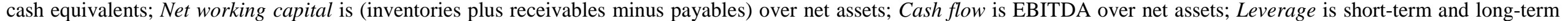

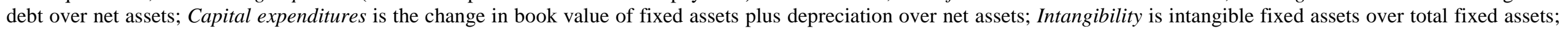

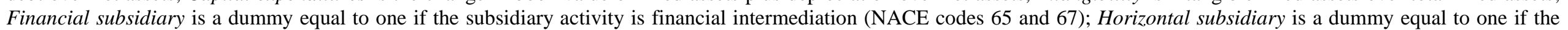

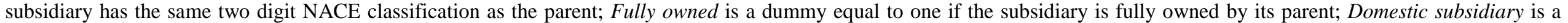

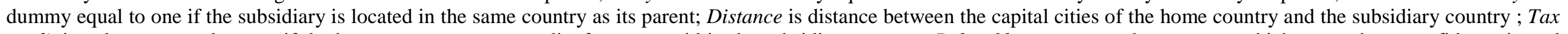

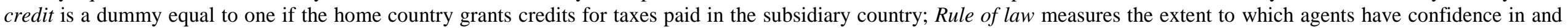

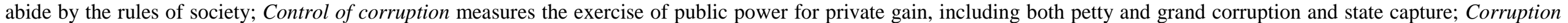
perception measures the perceived public sector corruption; Private credit is domestic credit to private sector as a $\%$ of GDP. 


\section{Table 4}

MNC consolidated cash holdings

\begin{tabular}{|c|c|c|c|}
\hline \multirow[t]{2}{*}{ Dependent variable: } & \multicolumn{3}{|c|}{ Ln(Cash holdings) } \\
\hline & (1) & (2) & (3) \\
\hline Home country CG measure: & Rule of law & $\begin{array}{l}\text { Control of } \\
\text { corruption }\end{array}$ & $\begin{array}{l}\text { Corruption } \\
\text { perception }\end{array}$ \\
\hline Home country CG & $\begin{array}{c}0.143 \\
(0.289)\end{array}$ & $\begin{array}{c}0.016 \\
(0.862)\end{array}$ & $\begin{array}{l}-0.006 \\
(0.826)\end{array}$ \\
\hline Home country private credit & $\begin{array}{c}-0.010 * * * \\
(0.000)\end{array}$ & $\begin{array}{c}-0.009^{* * *} * \\
(0.000)\end{array}$ & $\begin{array}{c}-0.009 * * * \\
(0.000)\end{array}$ \\
\hline Ln(Countries) & $\begin{array}{c}0.157 * * * \\
(0.000)\end{array}$ & $\begin{array}{c}0.158 * * * \\
(0.000)\end{array}$ & $\begin{array}{c}0.158 * * * \\
(0.000)\end{array}$ \\
\hline Ln(Net assets) & $\begin{array}{c}-0.027 * * * \\
(0.009)\end{array}$ & $\begin{array}{c}-0.027 * * * \\
(0.008)\end{array}$ & $\begin{array}{c}-0.027 * * * \\
(0.008)\end{array}$ \\
\hline Cash flow & $\begin{array}{c}0.405 \\
(0.119)\end{array}$ & $\begin{array}{c}0.406 \\
(0.120)\end{array}$ & $\begin{array}{c}0.406 \\
(0.120)\end{array}$ \\
\hline Leverage & $\begin{array}{c}-1.758^{* * * *} \\
(0.000)\end{array}$ & $\begin{array}{c}-1.753^{* * * *} \\
(0.000)\end{array}$ & $\begin{array}{c}-1.752 * * * \\
(0.000)\end{array}$ \\
\hline Net working capital & $\begin{array}{c}0.029 \\
(0.875)\end{array}$ & $\begin{array}{c}0.038 \\
(0.838)\end{array}$ & $\begin{array}{c}0.041 \\
(0.825)\end{array}$ \\
\hline Market-to-book & $\begin{array}{c}0.178 * * * \\
(0.000)\end{array}$ & $\begin{array}{c}0.176 * * * \\
(0.000)\end{array}$ & $\begin{array}{c}0.176 * * * \\
(0.000)\end{array}$ \\
\hline Intangibility & $\begin{array}{c}0.479 * * * \\
(0.000)\end{array}$ & $\begin{array}{c}0.473 * * * \\
(0.000)\end{array}$ & $\begin{array}{c}0.470 * * * \\
(0.000)\end{array}$ \\
\hline Industry and year fixed effects & Yes & Yes & Yes \\
\hline No. of observations & 6,545 & 6,545 & 6,545 \\
\hline R-Squared & 0.163 & 0.162 & 0.162 \\
\hline
\end{tabular}

Cash holdings is cash and cash equivalents over net assets; Rule of law measures the extent to which agents have confidence in and abide by the rules of society); Control of corruption measures the exercise of public power for private gain, including both petty and grand corruption and state capture; Corruption perception measures the perceived public sector corruption; Private credit is domestic credit to private sector as a \% of GDP; Countries is the number of countries (worldwide) in which the MNC has subsidiaries; Net assets is total assets minus cash and cash equivalents; Cash flow is EBITDA over net assets; Leverage is short-term and long-term debt over net assets; Net working capital is (inventories plus receivables minus payables) over net assets; Market-to-book is the market value over the book value of assets; Intangibility is intangible fixed assets over total fixed assets. Robust P-values in parentheses are based on standard errors clustered by firms. ***: denotes significance at the $1 \%$ level; **: denotes significance at the $5 \%$ level; *: denotes significance at the $10 \%$ level. 
Table 5

Subsidiary cash holdings and the headquarters-subsidiary relationship

Dependent variable:

Ln(Cash holdings)

(6)

\begin{tabular}{|c|c|c|c|}
\hline Subsidiaries: & All & Domestic & Foreign \\
\hline Domestic subsidiary & $\begin{array}{c}-0.471 * * * \\
(0.000)\end{array}$ & & \\
\hline Fully owned & $\begin{array}{c}-0.075 \\
(0.435)\end{array}$ & $\begin{array}{l}-0.070 \\
(0.593)\end{array}$ & $\begin{array}{c}-0.152 \\
(0.264)\end{array}$ \\
\hline Horizontal subsidiary & $\begin{array}{c}0.307 * * * \\
(0.000)\end{array}$ & $\begin{array}{c}0.316^{* * * *} \\
(0.003)\end{array}$ & $\begin{array}{c}0.287^{* *} * \\
(0.022)\end{array}$ \\
\hline Distance & & & $\begin{array}{c}-0.069 \\
(0.558)\end{array}$ \\
\hline Tax credit & & & $\begin{array}{c}0.418 \text { *** } \\
(0.001)\end{array}$ \\
\hline Ln(MNC cash holdings) & $\begin{array}{c}0.416^{* * *} \\
(0.000)\end{array}$ & $\begin{array}{c}0.478 * * * \\
(0.000)\end{array}$ & $\begin{array}{c}0.294 * * * \\
(0.000)\end{array}$ \\
\hline Ln(Net assets) & $\begin{array}{c}-0.291 * * * \\
(0.000)\end{array}$ & $\begin{array}{c}-0.263 * * * \\
(0.000)\end{array}$ & $\begin{array}{c}-0.333 * * * \\
(0.000)\end{array}$ \\
\hline Cash flow & $\begin{array}{c}2.147 * * * \\
(0.000)\end{array}$ & $\begin{array}{c}2.206^{* * * *} \\
(0.000)\end{array}$ & $\begin{array}{c}2.069 * * * \\
(0.000)\end{array}$ \\
\hline Leverage & $\begin{array}{c}0.487 * * * \\
(0.000)\end{array}$ & $\begin{array}{c}0.662 * * * \\
(0.000)\end{array}$ & $\begin{array}{c}0.017 \\
(0.913)\end{array}$ \\
\hline Net working capital & $\begin{array}{c}-0.235 \\
(0.105)\end{array}$ & $\begin{array}{c}-0.195 \\
(0.359)\end{array}$ & $\begin{array}{l}-0.199 \\
(0.272)\end{array}$ \\
\hline Capital expenditures & $\begin{array}{c}-1.017 * * * \\
(0.000)\end{array}$ & $\begin{array}{c}-1.150 * * * \\
(0.000)\end{array}$ & $\begin{array}{c}-0.737 * * * \\
(0.009)\end{array}$ \\
\hline Intangibility & $\begin{array}{c}0.409 * * * \\
(0.003)\end{array}$ & $\begin{array}{c}0.530 * * * \\
(0.003)\end{array}$ & $\begin{array}{c}0.128 \\
(0.541)\end{array}$ \\
\hline Financial subsidiary & $\begin{array}{c}-0.834 * \\
(0.071)\end{array}$ & $\begin{array}{c}0.246 \\
(0.670)\end{array}$ & $\begin{array}{c}-1.604 * * * \\
(0.003)\end{array}$ \\
\hline Industry and year fixed effects & Yes & Yes & Yes \\
\hline No. of observations & 13,321 & 8,321 & 5,000 \\
\hline R-Squared & 0.180 & 0.187 & 0.191 \\
\hline
\end{tabular}

Cash holdings is cash and cash equivalents over net assets; Domestic subsidiary is a dummy equal to one if the subsidiary is located in the same country as its parent; Fully owned is a dummy equal to one if the subsidiary is fully owned by its parent; Horizontal subsidiary is a dummy equal to one if the subsidiary has the same two digit NACE classification as the parent; Distance is the distance between the capital cities of the home country and the subsidiary country; Tax credit is a dummy equal to one if the home country grants credits for taxes paid in the subsidiary country; MNC cash holdings is MNC cash and cash equivalents over MNC net assets; Net assets is total assets minus cash and cash equivalents; Cash flow is EBITDA over net assets; Leverage is short-term and long-term debt over net assets; net working capital is (inventories plus receivables minus payables) over net assets; Capital expenditures is the change in book value of fixed assets plus depreciation over net assets; Intangibility is intangible fixed assets over total fixed assets; Financial subsidiary is a dummy equal to one if the subsidiary activity is financial intermediation (NACE codes 65 and 67). P-values in parentheses are based on standard errors clustered by MNCs and subsidiaries. ***: denotes significance at the $1 \%$ level; $* *$ : denotes significance at the $5 \%$ level; *: denotes significance at the $10 \%$ level. 
Table 6

Subsidiary cash holdings and country-level corporate governance

\begin{tabular}{lccc}
\hline \multicolumn{1}{c}{ Dependent variable: } & \multicolumn{2}{c}{ Ln(Cash holdings) } & $(9)$ \\
\multicolumn{1}{c}{ Subsidiaries: } & $(7)$ & $(8)$ & Foreign \\
Subsidiary country CG measure: & Foreign & Foreign & Corruption \\
pule of law & Control of & perception \\
\hline Subsidiary country CG & & corruption & $0.107 * *$ \\
Subsidiary country private credit & $0.602^{* * *}$ & $0.395^{* * *}$ & $(0.023)$ \\
& $(0.005)$ & $(0.009)$ & $-0.005^{*}$ \\
Fully owned & $-0.005^{* *}$ & $-0.005^{* *}$ & $(0.074)$ \\
& $(0.042)$ & $(0.040)$ & -0.166 \\
Horizontal subsidiary & -0.167 & -0.172 & $(0.221)$ \\
& $(0.219)$ & $(0.206)$ & $0.284^{* *}$ \\
Distance & $0.285^{* *}$ & $0.282^{* *}$ & $(0.023)$ \\
& $(0.023)$ & $(0.024)$ & -0.029 \\
Control variables included & 0.034 & 0.004 & $(0.810)$ \\
No. of observations & $(0.788)$ & $(0.975)$ & Yes \\
R-Squared & Yes & Yes & 5,000 \\
\hline Cash & 5,000 & 5,000 & 0.194
\end{tabular}

Cash holdings is cash and cash equivalents over net assets; Rule of law measures the extent to which agents have confidence in and abide by the rules of society; Control of corruption measures the exercise of public power for private gain, including both petty and grand corruption and state capture; Corruption perception measures the perceived public sector corruption; Private credit is domestic credit to private sector as a \% of GDP; Fully owned is a dummy equal to one if the subsidiary is fully owned by its parent; Horizontal subsidiary is a dummy equal to one if the subsidiary has the same two digit NACE classification as the parent; Distance is the distance between the capital cities of the home country and the subsidiary country. Control variables are Tax credit, which is a dummy equal to one if the home country grants credits for taxes paid in the subsidiary country; MNC cash holdings, which is MNC cash and cash equivalents over MNC net assets; Net assets which is total assets minus cash and cash equivalents; Cash flow which is EBITDA over net assets; Leverage which is short-term and longterm debt over net assets; Net working capital which is (inventories plus receivables minus payables) over net assets; Capital expenditures which is the change in book value of fixed assets plus depreciation over net assets; Intangibility which is intangible fixed assets over total fixed assets; Financial subsidiary which is a dummy equal to one if the subsidiary activity is financial intermediation (NACE codes 65 and 67); industry and year fixed effects. P-values in parentheses are based on standard errors clustered by MNCs and subsidiaries. ***: denotes significance at the $1 \%$ level; **: denotes significance at the 5\% level; *: denotes significance at the $10 \%$ level. 
Table 7

Subsidiary cash holdings - MNCs and subsidiaries outside the UK and France

Dependent variable:

Subsidiaries:

All

Subsidiary country CG measure:
Ln(Cash holdings)

Domestic

\author{
Foreign
}

Foreign

Foreign

Rule of law

\begin{tabular}{lccccc}
\hline Domestic subsidiary & $\begin{array}{c}-0.817 * * * \\
(0.000)\end{array}$ & & & \\
& & & & \\
Subsidiary country CG & & & $0.933^{* * *}$ & $0.605^{* *}$ & $\begin{array}{c}0.161^{* *} \\
(0.023)\end{array}$ \\
& & $(0.004)$ & $(0.012)$ & $-0.008^{* *}$ \\
Subsidiary country private credit & & $-0.010^{* * *}$ & $-0.010^{* * *}$ & $(0.015)$ \\
& & & $(0.003)$ & $(0.005)$ & $-0.533^{*}$ \\
Fully owned & -0.222 & -0.056 & $-0.512^{*}$ & $-0.547 *$ & $(0.052)$ \\
& $(0.256)$ & $(0.837)$ & $(0.070)$ & $(0.053)$ & $0.484 * *$ \\
Horizontal subsidiary & $0.403 * * *$ & $0.350 *$ & $0.486 * *$ & $0.484 * *$ & $(0.020)$ \\
& $(0.006)$ & $(0.071)$ & $(0.021)$ & $(0.021)$ & -0.107 \\
Distance & & & 0.018 & -0.025 & $(0.632)$ \\
Control variables included & & & $(0.936)$ & $(0.913)$ & Yes \\
No. of observations & Yes & Yes & Yes & Yes & 1,745 \\
R-Squared & 3,927 & 2,182 & 1,745 & 1,745 & 0.202 \\
\hline
\end{tabular}

Cash holdings is cash and cash equivalents over net assets; Rule of law measures the extent to which agents have confidence in and abide by the rules of society; Control of corruption measures the exercise of public power for private gain, including both petty and grand corruption and state capture; Corruption perception measures the perceived public sector corruption; private credit is domestic credit to private sector as a \% of GDP; Domestic subsidiary is a dummy equal to one if the subsidiary is located in the same country as its parent; Fully owned is a dummy equal to one if the subsidiary is fully owned by its parent; Horizontal subsidiary is a dummy equal to one if the subsidiary has the same two digit NACE classification as the parent; Distance is the distance between the capital cities of the home country and the subsidiary country. Control variables are Tax credit, which is a dummy equal to one if the home country grants credits for taxes paid in the subsidiary country; MNC cash holdings, which is MNC cash and cash equivalents over MNC net assets; Net assets which is total assets minus cash and cash equivalents; Cash flow which is EBITDA over net assets; Leverage which is short-term and long-term debt over net assets; Net working capital which is (inventories plus receivables minus payables) over net assets; Capital expenditures which is the change in book value of fixed assets plus depreciation over net assets; Intangibility which is intangible fixed assets over total fixed assets; Financial subsidiary which is a dummy equal to one if the subsidiary activity is financial intermediation (NACE codes 65 and 67); industry and year fixed effects. P-values in parentheses are based on standard errors clustered by MNCs and subsidiaries. ***: denotes significance at the $1 \%$ level; **: denotes significance at the $5 \%$ level; *: denotes significance at the $10 \%$ level. 